\title{
Analysis of fire resistance of concrete with polypropylene or steel fibers
}

\author{
Rubén Serrano, Alfonso Cobo, María Isabel Prieto*, María de las Nieves González
}

Technical University of Madrid, Madrid, Spain

\begin{abstract}
A B S T R A C T
The decrease in concrete resistance and the expansion generated in reinforced concrete structures by direct exposure to fire at $400{ }^{\circ} \mathrm{C}$ maximum temperature serves as the basis for the present research. The aim is to improve these problems by the addition of steel fibers or of polypropylene fibers in concrete. From the results analysis of compression fracture tests on cylindrical concrete specimens, it can be concluded that concrete with addition of polypropylene fibers or steel fibers are a good alternative to traditional concrete, because both its strength, and its behavior in case of fire are improved, delaying the appearance of fissures and explosive concrete spalling.
\end{abstract}

\section{Introduction}

Given the importance of concrete as a structural material and the significance of preserving its stability in case of fire, advancing in the research of materials and systems that improve their behavior has become a need, because fire reduces concrete resistant capacity and rigidity and generates deformations imposed during the fire and the cooling phase [1,2].

Concrete subjected to early stages of fire has no noticeable loss of qualities, and rather, it increases its mechanical strength when up to $280^{\circ} \mathrm{C}$, maintaining a grey appearance. From $280^{\circ} \mathrm{C}$ onwards, the mechanical ability of concrete decreases, reaching a compressive strength loss of $15 \%$ at around $400{ }^{\circ} \mathrm{C}$. This decisively influences the way to work and the type of exposure to fire of the structural element [3].

In addition to resistance, the decrease of the longitudinal elasticity module of concrete is of utmost importance, decreasing up

* Corresponding author at: Technical University of Madrid, Avda. Juan de Herrera, 6, 28040 Madrid, Spain.

E-mail address: mariaisabel.prieto@upm.es (M.I. Prieto). to $75 \%$, when the temperature rises from $20^{\circ} \mathrm{C}$ to $400{ }^{\circ} \mathrm{C}$. In addition, this thermal gradient produces expansion differences between the different faces of the structural element regarding their exposure to fire, resulting in differences in strain and high tensile stresses, that produce concrete cracking [4-7].

The addition of steel fibers modifies the nonlinear behavior of structural concrete, especially its tensile strength, preventing the opening and propagation of cracks and increasing its ductility [8-12].

Concrete reinforced with polypropylene fibers, due to the physical and mechanical properties of the fibers, reduces the permeability and capillar porosity blocking the pores in the concrete. These improvements are achieved with the optimal amount of polypropylene of $0.7 \mathrm{~kg} / \mathrm{m}^{3}$ [13-16].

The addition of metallic fibers in concrete, when subjected to fire, produces a positive influence, improving energy absorption and reducing cracking [17-19]. In the case of the addition of polypropylene fibers, the ability to reduce cracking is due to fact that concrete permeability increases suddenly between $80^{\circ} \mathrm{C}$ and $130{ }^{\circ} \mathrm{C}$, and polypropylene, once it has reached the melting point, flows through the cracks and produces channels allowing the 
water vapor and gases to be evacuated releasing the pore pressure [20-28]. Although there are numerous research works on the behavior of concrete elements to fire, no literature has been found about concrete elements subjected to compression in the range of temperatures studied in the present work, neither when subjected to a direct fire test, nor comparisons performance to fire of concrete with steel and polypropylene fibers.

Based on the above premises, the aim of this research is to compare the mechanical behavior of concrete with addition of metallic fibers, with concrete with polypropylene fibers, when exposed to direct fire action, with maximum temperatures of around $400{ }^{\circ} \mathrm{C}$. Likewise, the mechanical behavior of these concretes will be compared with concrete without fibers, both exposed to fire and at room temperature.

\section{Experimental testing}

\subsection{Materials}

For the development of the experimental work, the following equipment and materials listed below were used.

Materials used:

- Cement type CEM II/BL 32,5 for the three batches, according to the standards UNE-EN 197-1:2011 and RC-08 [29,30].

- Washed fine river sand with 0-4 mm granulometry fraction, of washed siliceous nature, according to the standard UNE-EN 13139/AC:2004 [31].

- Coarse aggregate with 4-20 mm granulometric fraction, of washed siliceous nature, and a maximum aggregate size of $12 \mathrm{~mm}$, according to the standard UNE-EN 12620:2003 + A1:2009 [32].

- Water from the Canal de Isabel II of Madrid water supply system, since it meets the technical requirements established for structural concrete.

- Straight drawn steel fibers with hooks at the edges of each fiber (Sika Fiber CHO65/35 NB). They comply with the standard ASTM A 820-Type 1.

- Monofilament polypropylene fibers (SIKA Sikafiber M-12). They comply with the standard UNE 14889-2: Polymer fibers for concrete. Class 1-a: "Monofilament Microfiber".

- No additives have been used.

The proportions used in the various batches are shown in Table 1.

Fig. 1 shows the appearance of the steel and polypropylene fibers employed and the fiber characteristics are shown in Table 2.

\subsection{Testing program}

In order to achieve the objective of the present research, we have studied the behavior in compression in concrete specimens

Table 1

Proportions of the batches and material content according to addition.

\begin{tabular}{|c|c|c|c|c|c|}
\hline \multirow{3}{*}{$\begin{array}{l}\text { Type of } \\
\text { concrete } \\
\text { Batch }\end{array}$} & \multicolumn{5}{|l|}{ HM-25 } \\
\hline & \multirow{2}{*}{\begin{tabular}{l}
\multicolumn{1}{c}{1} \\
No \\
addition
\end{tabular}} & \multicolumn{2}{|r|}{2} & \multicolumn{2}{|c|}{3} \\
\hline & & $\begin{array}{l}\text { Steel } \\
\text { fibers }\end{array}$ & $\begin{array}{l}\text { Steel } \\
\text { fibers }\end{array}$ & $\begin{array}{l}\text { Polypropylene } \\
\text { fibers }\end{array}$ & $\begin{array}{l}\text { Polypropylene } \\
\text { fibers }\end{array}$ \\
\hline $\begin{array}{l}\mathrm{N}^{\circ} \text { of } \\
\text { specimens }\end{array}$ & 6 & 6 & 6 & 6 & 6 \\
\hline Cement (kg) & 4.088 & 4.088 & 4.088 & 4.088 & 4.088 \\
\hline Sand (kg) & 8.472 & 8.472 & 8.472 & 8.472 & 8.472 \\
\hline Gravel (kg) & 14.616 & 14.616 & 14.616 & 14.616 & 14.616 \\
\hline Water (l) & 2.040 & 2.040 & 2.040 & 2.040 & 2.040 \\
\hline Addition (\%) & 0 & 1 & 2 & 1 & 2 \\
\hline
\end{tabular}

without additions and with different percentages of fibers of steel and polypropylene, in accordance with Spanish Structural Concrete standard, annex 14 of the EHE [33], for manufacturing fiberreinforced concrete. A group of specimens has initially been tested to fire, and later tested to fracture in compressive strength, in order to compare it with the performance of specimens not subjected to thermal aggression, and to establish results of strength, resistance, strain and energy density deformation, both maximum and ultimate ones.

To perform the analysis, 30 cylindrical test pieces have been made, $100 \mathrm{~mm}$ in diameter and $200 \mathrm{~mm}$ in height, according to the standard UNE-EN 12390-1:2013 [34]. The testing program was organized in three batches; with the first one, 6 specimens of concrete without additions were made. With the second batch, 12 specimens were elaborated with addition of steel fibers, of which 6 were made with $1 \%$ proportion of steel fiber in cement weight, and the other 6 specimens, with $2 \%$ addition. With the third and last batch, another 12 specimens were produced; in this case incorporating polymeric fibers of polypropylene: 6 of them with $1 \%$ addition and the other remaining 6 with $2 \%$ of polypropylene fibers per cement weight. From each of the specimen groups performed, $50 \%$ specimens were tested directly to fracture by compression, according to the standard UNE-EN 12390-3:2009 [35], while the remaining $50 \%$, were first subjected to the direct fire test in accordance to the fire resistance tests of materials used by the Fire Prevention and Extinction Service of Madrid Autonomous region and the standards UNE-EN 1363-1:2012, UNE-EN 1363$2: 2000$ and UNE-EN 1365-4:2000 [36-38]. Once cooled, they were also tested in compression.

The nomenclature and the tests carried out on the specimens can be seen in Table 3 .

\subsection{Experimental process}

Firstly, and before starting the manufacture of the concrete specimens, materials necessary for the preparation of the test specimens listed in Table 1 were kept $24 \mathrm{~h}$ in laboratory conditions. Gravel was sifted through a mechanical sieve, in order to ensure that there was no aggregate larger than $12 \mathrm{~mm}$. Each of the materials used, cement, sand, gravel, fibers and water were separately weighed, with a dial type industrial scale and with a digital scale, according to the required precision.

Kneading of the specimens batches was carried out in a planetary mixer of vertical axis IBERTEST CIB-701 model, upgraded to IB32-040V0, where the materials were introduced in the following order: gravel, cement, and finally, sand, while specimens with additions were individually manually mixed, to ensure a perfect distribution of the fibers.

Once all materials were incorporated in the mixer, except water, the mixing process began with the help of the rotary blades of the mixer, mixing the dry materials for approximately $2 \mathrm{~min}$ in order to homogenize the batch. Later, water was progressively poured, taking into account the moisture content of the aggregate until a plastic consistency of concrete was reached, for approximately 5 min.

Once the concrete for each of the 3 batches was finished, the molds were filled up, according to the fresh concrete testing standard UNE-EN 12390-2 [39]. And after each mold was filled with three concreting lifts, they were compacted with a compactor steel bar. Specimens were made up to volume and were kept for $24 \mathrm{~h}$ at laboratory temperature of approximately $22^{\circ} \mathrm{C}\left( \pm 3{ }^{\circ} \mathrm{C}\right)$ and an approximate relative humidity of $60 \%$, before they were unmolded.

After $24 \mathrm{~h}$, specimens were unmolded and kept in a curing chamber at $20^{\circ} \mathrm{C}\left( \pm 2{ }^{\circ} \mathrm{C}\right)$ temperature and relative humidity $\geqslant 95 \%$ for 28 days, for curing, hardening and for performing the subsequent study of fracture compression tests and fire tests, 

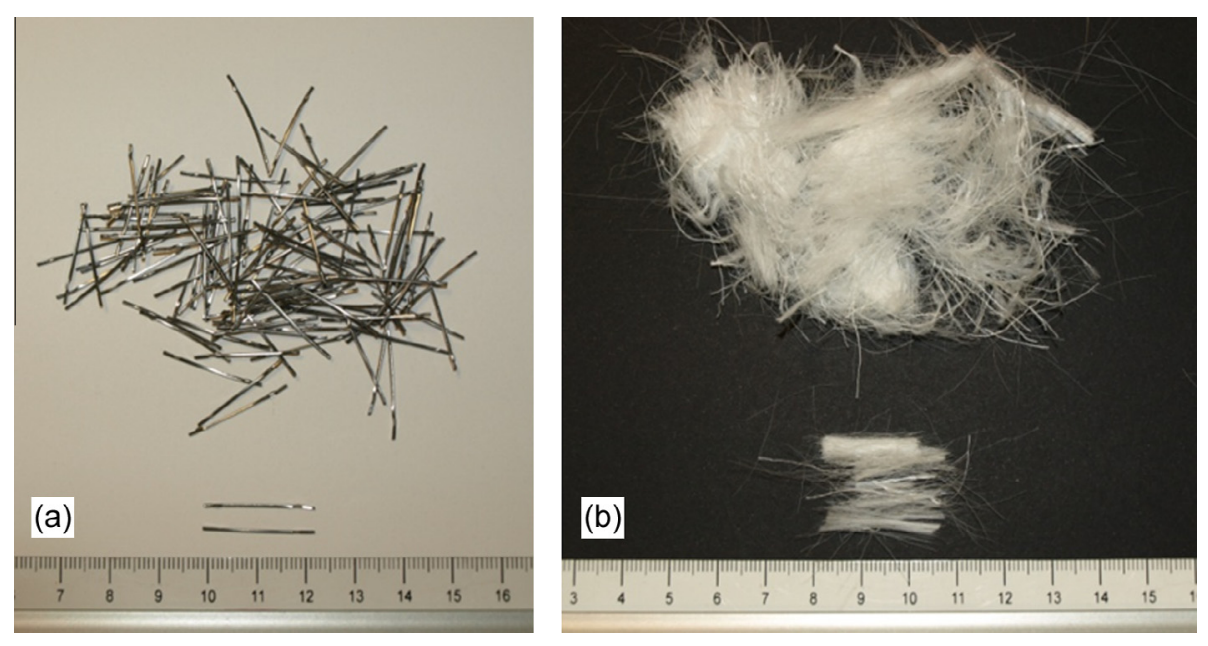

Fig. 1. Appearance of the fibers employed (a) metallic fibers, (b) polypropylene fibers.

Table 2

Fiber characteristics.

\begin{tabular}{lllll}
\hline Materials & $\begin{array}{l}\text { Density } \\
\left(\mathrm{g} / \mathrm{cm}^{3}\right)\end{array}$ & Geometry and size & $\begin{array}{l}\text { Quantity } \\
\text { (units } / \mathrm{kg})\end{array}$ & $\begin{array}{l}\text { Melting } \\
\text { point }\left({ }^{\circ} \mathrm{C}\right)\end{array}$ \\
\hline Steel fiber & 7.85 & $\begin{array}{l}\text { Hooked } \mathrm{l}_{\mathrm{f}}=35 \mathrm{~mm}, \\
\mathrm{~d}_{\mathrm{f}}=0.54 \mathrm{~mm} \mathrm{~L} / \mathrm{D}:\end{array}$ & 15,900 & - \\
& & $\begin{array}{l}65 \pm 15 \% \\
\text { Straight } \mathrm{l}_{\mathrm{f}}=12 \mathrm{~mm}, \\
\mathrm{~d}_{\mathrm{f}}=31 \mu \mathrm{m}\end{array}$ & 102 millions 170 \\
$\begin{array}{c}\text { Polypropylene } \\
\text { fiber }\end{array}$ & 0.91 & & \\
\hline
\end{tabular}

Table 3

Nomenclature and tests performed on concrete specimens.

\begin{tabular}{lcllll}
\hline Batch & \multicolumn{1}{c}{1} & \multicolumn{2}{c}{2} & \multicolumn{2}{l}{3} \\
\hline Compression test & SA-P1 & FA-1\%.P1 & FA-2\%.P1 & PP-1\%.P1 & PP-2\%.P1 \\
& SA-P2 & FA-1\%.P2 & FA-2\%.P2 & PP-1\%.P2 & PP-2\%.P2 \\
& SA-P3 & FA-1\%.P3 & FA-2\%.P3 & PP-1\%.P3 & PP-2\%.P3 \\
Fire + compression & SA-P4.F & FA-1\%.P4.F & FA-2\%.P4.F & PP-1\%.P4.F & PP-2\%.P4.F \\
test & SA-P5.F & FA-1\%.P5.F & FA-2\%.P5.F & PP-1\%.P5.F & PP-2\%.P5.F \\
& SA-P6.F & FA-1\%.P6.F & FA-2\%.P6.F & PP-1\%.P6.F & PP-2\%.P6.F \\
\hline
\end{tabular}

which are detailed in next section. The process of implementation of concrete specimens can be seen in Fig. 2.

\subsection{Types of tests}

To evaluate the influence of fire action on concrete compressive strength behavior, resistance to direct and real fire tests established by the fire service of the Madrid Region were carried out, and the subsequent fracture tests in compression in concrete specimens with and without additions were performed.

The direct fire resistance test was carried out according to the ISO R-834 standard [40], considering a calorific potential of $40 \mathrm{~kg}$ of wood per square meter $\left(\mathrm{kg} / \mathrm{m}^{2}\right)$, which is equivalent to the mean value of the calorific potential in building fires. For performing the test, specimens were placed vertically as a supporting element of a building, leaving all sides in direct contact with the fire. They were placed on a steel grill on top of a test tray of $1 \mathrm{~m}^{2}$ surface, loaded with $40 \mathrm{~kg}$ of chopped wood, sprayed with gasoline to promote combustion at the start. The test lasted $1 \mathrm{~h}$, measuring the temperature on the surface of the specimens at 15, 30, 45 and $60 \mathrm{~min}$, using an infrared thermometer compact model "Testo 845". After $1 \mathrm{~h}$ of fire exposure, the specimens slowly cooled down. The fire test is shown in Fig. 3.
Before performing the fracture compression test, the specimens were submitted to facing operation with sulphur mortar according to UNE-EN 12390-3:2009 [35]. In order to carry out the compression test, specimens were placed in the universal press, where a preload of $10 \%$ of the maximum test load was applied, so that the top plate would be uniformly supported on the upper face of the test piece. At that moment, the compression test was performed by measuring the piston stroke, in order to obtain the strength and the strain elongation, which would fulfill the objective of the present research work, as can be seen in Fig. 4.

\section{Results and analysis}

Results obtained in the compression test of concrete at room temperature are shown in Fig. 5, using the most representative graph for each case, and showing the strength-strain evolution in the specimens without addition, and in the ones with different addition percentages. As can be seen, strengths values are higher in specimens with additions. Similar behaviors can be observed for 1 and 2\% percentages of each addition, and at the same time, a better behavior is achieved with the addition of polypropylene fibers.

Fig. 6 shows the temperature evolution regarding time in the direct fire test on specimens without addition and with different addition types and percentages ( $1 \%$ and $2 \%$ ) by cement weight. As can be seen, specimens experience the highest temperatures within the first $45 \mathrm{~min}$ of the fire start, reaching peaks of $413^{\circ} \mathrm{C}$ in concretes with metallic fiber addition, $337^{\circ} \mathrm{C}$ and $380^{\circ} \mathrm{C}$ in specimens without additions and with addition of polypropylene fibers respectively. A different cooling process is shown between concrete with and without additions. The calculation of fire severity, obtained as the area under the temperature-time curve, shows the most elevated value $\left(14,440{ }^{\circ} \mathrm{C} \mathrm{min}\right)$ in specimens with steel fiber addition, and shows similar and lower values for concretes without additions $\left(11,217.5^{\circ} \mathrm{C}\right.$ min $)$ and concrete with polypropylene fibers $\left(11,490^{\circ} \mathrm{C} \mathrm{min}\right)$. These results show that specimens with metallic fiber addition have suffered the fire action more intensely than the specimens without addition or with polypropylene fibers. These results agree with other research results published, where it is proved that in concrete subjected to high temperatures, the addition of steel fibers increases concrete porosity but to a lesser extent than in the case of the addition of polypropylene fibers, reducing pressure in the pores in the deeper concrete areas, and contributing to the confinement of dehydrated 

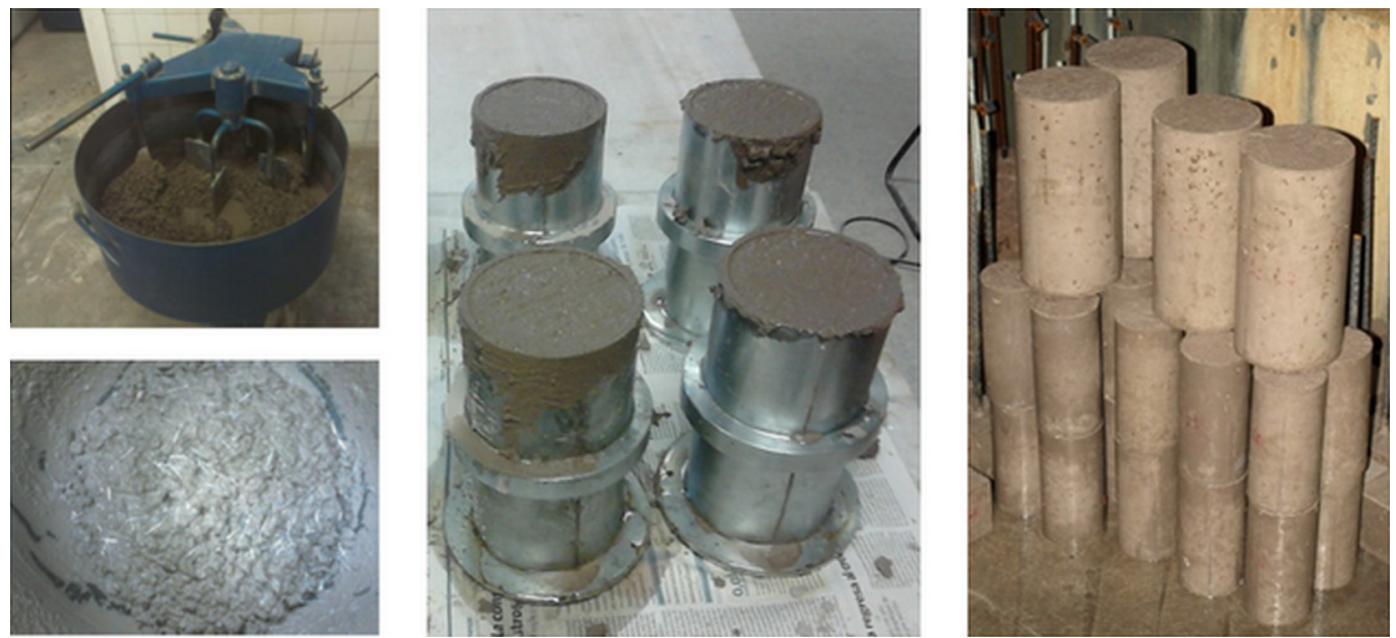

Fig. 2. Manufacture and curing of cylindrical specimens with and without addition.
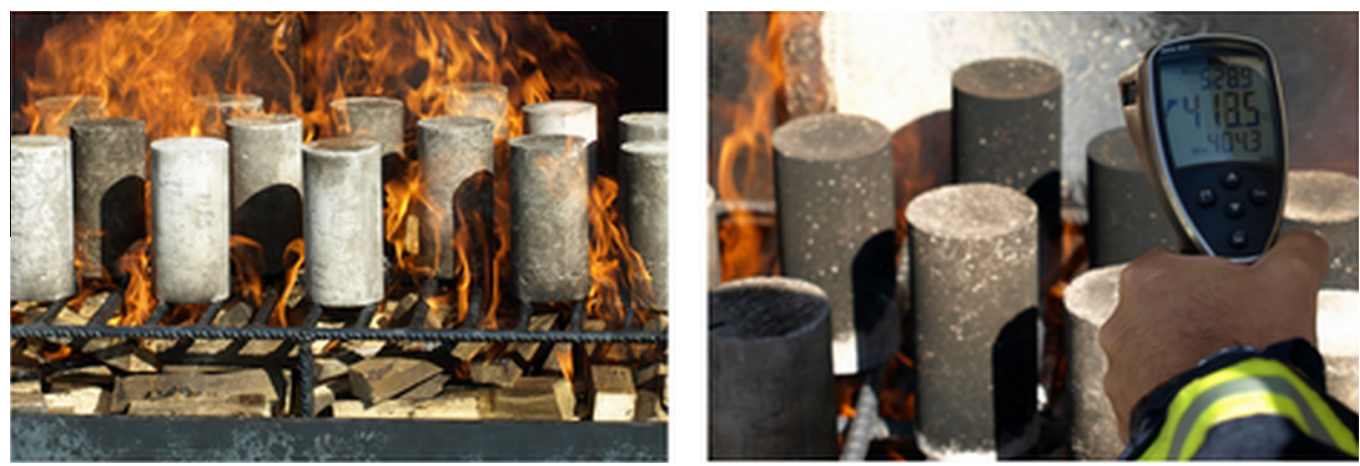

Fig. 3. Fire test with direct exposure to the flames of the specimen surface, and measurement with infrared thermometer.
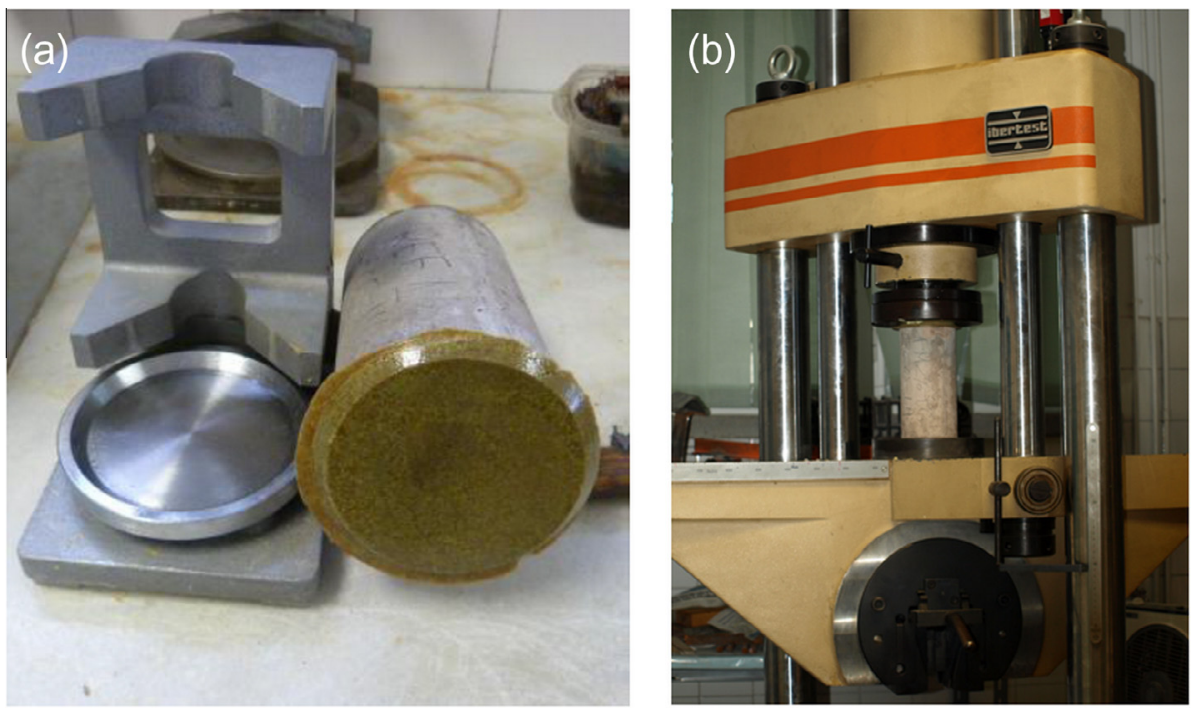

Fig. 4. Specimen facing (a) and compression test (b).

paste and controlling cracking [28,41,42]. The addition of polypropylene fibers in concrete, when the melting point is reached $\left(170^{\circ} \mathrm{C}\right)$, creates a series of channels in the concrete mass that allows water vapor to evacuate, releasing pore pressure, gradually reducing the temperature, and decreasing the cracks in the cooling phase $[25,27,43]$. The similarity of the severity values between concrete without fibers and with polypropylene fibers is because concrete with polypropylene fibers reaches lower temperatures due to the porosity increase, but since the cooling process is slower, the area under the temperature-time curve is compensated with the higher temperature reached by concrete without fibers, but with a much quicker cooling. 


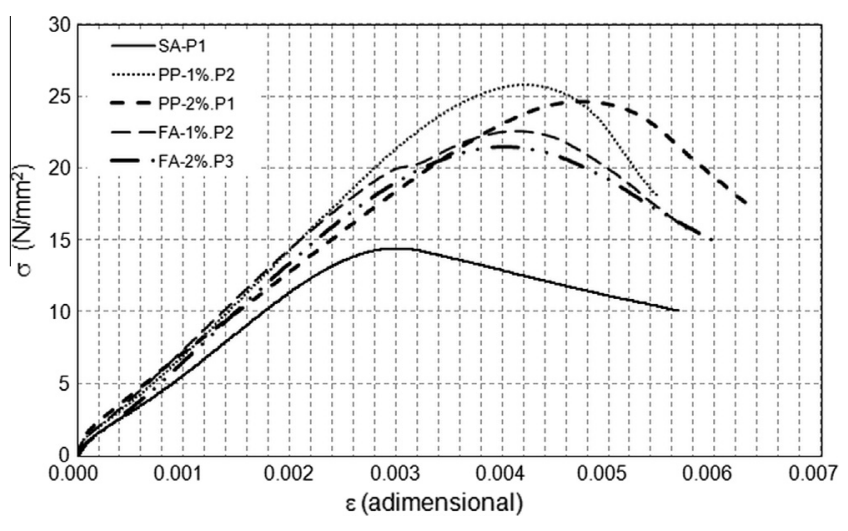

Fig. 5. Evolution of strength $(\sigma)$-strain $(\varepsilon)$ behavior in specimens without addition, with percentages of $1-2 \%$ of polypropylene fibers and with percentages of the 1 and $2 \%$ of steel fibers, before being tested to direct fire.

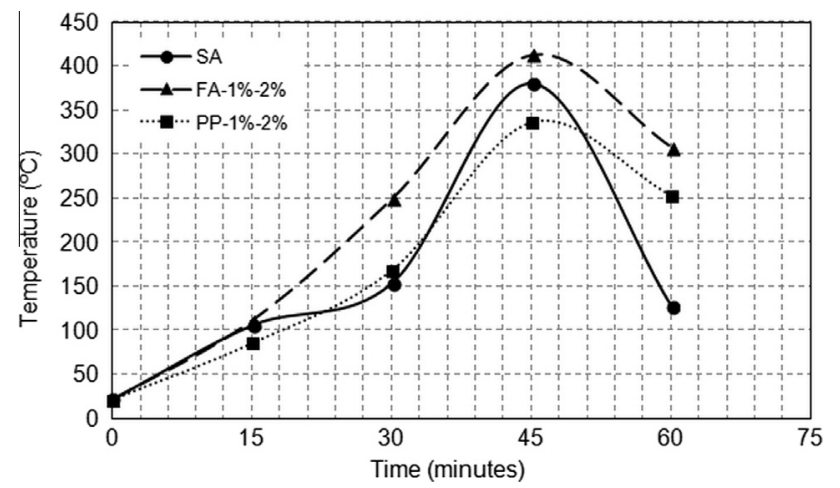

Fig. 6. Temperature evolution regarding time exposure of specimens without addition, with percentages of the 1 and $2 \%$ of polypropylene fibers and from 1 to $2 \%$ of steel fiber percentages.

Fig. 7 shows the strength-strain evolution of specimens without addition and with percentages of the 1 and $2 \%$ addition by cement weight, after having been submitted to the fire test. As can be seen, the greatest strength values are reached in specimens with polypropylene fibers, followed by specimens with steel fibers, and with lower strengths in specimens without additions, obtaining similar results in both percentages for each addition type.

Once having shown the most representative graphs of the compression tests (Figs. 5 and 7), in Table 4, means of the most

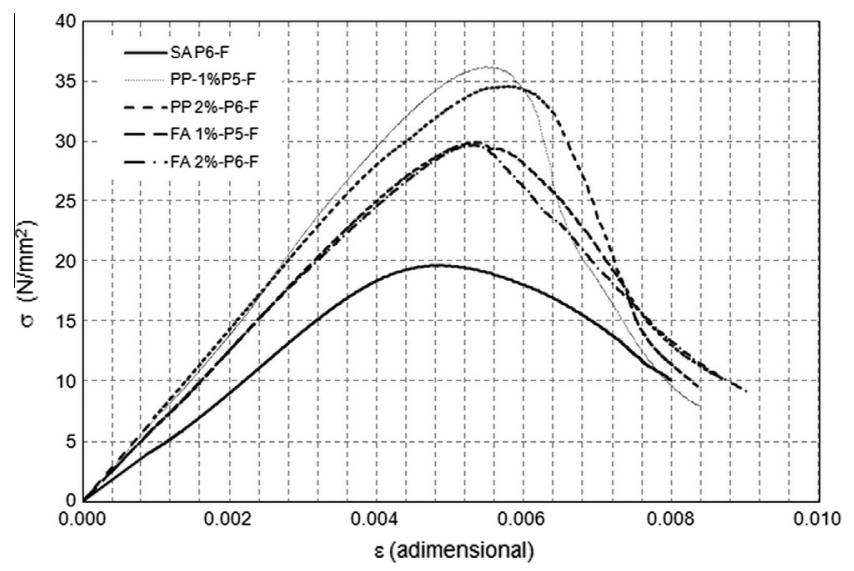

Fig. 7. Evolution of strength $(\sigma)$ - strain $(\varepsilon)$ in specimens without addition, with 1 and $2 \%$ percentages of polypropylene fibers and with percentages from 1 and $2 \%$ steel fibers, after the direct fire test. representative data values are displayed: maximum strength $\left(\sigma_{\max }\right)$, strain for maximum strength $\left(\varepsilon_{\max }\right)$, ultimate strength $\left(\sigma_{\mathrm{u}}\right)$, ultimate strain $\left(\varepsilon_{\mathrm{u}}\right)$, maximum deformation energy density $\left(E_{\max }\right)$ and ultimate deformation energy density $\left(E_{\mathrm{u}}\right)$.

Fig. 8 shows the results produced in the compressive strength test in the specimens with and without additions, and before and after the direct fire test. As can be seen, the specimens without addition present an explosive fracture, with wide and deep cracks, showing the material crushing prior to the structural collapse; while the specimens with additions, before and after the test fire, show a less explosive break.

\section{Discussion}

The analysis of the compression test results displayed in Table 4 show that the specimens once subjected to the direct fire test increase their maximum strength $\left(\sigma_{\max }\right)$, while diminishing the ultimate strength $\left(\sigma_{\mathrm{u}}\right)$. In terms of deformation and strain energy, both the ultimate and maximum ones, suffer an increase in concrete specimens after the fire test.

Fig. 9 allows us to compare the mean values corresponding to maximum strength and maximum strain, before and after being subjected to direct fire tests, taking as a reference the concrete without additions and not being subjected to fire. As can be seen, before submitting the specimens to the fire test, higher strengths are reached in the specimens with polypropylene, decreasing with the addition of steel and being quite smaller in the specimens without addition, while having similar behaviors with 1 and $2 \%$ additions. The maximum deformations with lower values are produced in specimens with additions of $2 \%$ steel fiber and specimens without additions. The other cases show similar maximum strain values. Once subjected to the fire test, specimens with $1 \%$ addition have a better performance than the specimens with $2 \%$, reaching in all cases strengths greater than specimens without additions. Maximum deformations are similar in specimens with additions, and they exceed those of the specimens without addition.

Fig. 10 allows to compare the evolution of the mean values corresponding to the ultimate strength and strains calculated from the compression test, before and after being subjected to direct fire test, taking as a reference concrete without additions and without fire. We are able to observe that ultimate strengths before the fire test are higher in specimens with additions, especially when the addition is polypropylene fiber, while ultimate strains are similar in all cases. Once the fire test is performed, both ultimate strength and ultimate strain are similar in all cases.

Fig. 11 allows comparing the evolution of the maximum and ultimate strain energy density before and after the fire test, taking as a reference concrete without additions and direct fire. As can be observed, strain energy densities are higher in specimens with additions, reaching the highest values with the addition of $2 \%$ polypropylene fiber before the fire test, and with $1 \%$ polypropylene fiber once subjected to the fire action.

Fig. 12 shows temperature values reached by the specimens with and without additions during the direct fire test. As Fig. 12a shows, the presence of $1 \%$ fibers in concrete makes the temperature increase more rapidly than in any of the other cases. However, it decreases more gradually, while with an addition of $1 \%$ polypropylene, the temperature increases more slowly, reaching lower values. Specimens without addition, besides reaching a higher mean temperature, cool quickly favoring the appearance of fissures. Fig. 12b shows that when increasing the addition percentage up to $2 \%$, the temperature increase is similar in all specimens up to $45 \mathrm{~min}$, when highest temperatures are reached in specimens with addition of steel fibers and lower ones with polypropylene fiber specimens. At this point, a gradual cooling is 
Table 4

Most representative mean values of the three specimens for each concrete type subjected to compression test and direct fire test, with the different addition percentages.

\begin{tabular}{|c|c|c|c|c|c|c|c|}
\hline & Addition fibers & $\begin{array}{l}\sigma_{\max } \\
\left(\mathrm{N} / \mathrm{mm}^{2}\right)\end{array}$ & $\begin{array}{l}\sigma_{\mathrm{u}} \\
\left(\mathrm{N} / \mathrm{mm}^{2}\right)\end{array}$ & $\begin{array}{l}\varepsilon_{\max } \times 10^{-3} \\
(\text { adimensional })\end{array}$ & $\begin{array}{l}\varepsilon_{\mathrm{u}} \times 10^{-3} \\
\text { (adimensional) }\end{array}$ & $\begin{array}{l}\mathrm{E}_{\max } \times 10^{-2} \\
\left(\mathrm{~N} / \mathrm{mm}^{2}\right)\end{array}$ & $\begin{array}{l}\mathrm{E}_{\mathrm{u}} \times 10^{-2} \\
\left(\mathrm{~N} / \mathrm{mm}^{2}\right)\end{array}$ \\
\hline \multirow[t]{5}{*}{ Compression tests } & Without addition & 14.372 & 10.063 & 3.117 & 5.956 & 2.755 & 6.217 \\
\hline & Polypropylene $1 \%$ & 25.051 & 17.963 & 4.222 & 5.368 & 5.993 & 8.610 \\
\hline & Polypropylene $2 \%$ & 24.933 & 17.462 & 4.413 & 5.819 & 6.256 & 9.330 \\
\hline & Steel 1\% & 21.088 & 14.769 & 4.159 & 5.742 & 5.183 & 8.102 \\
\hline & Steel $2 \%$ & 21.993 & 15.399 & 2.505 & 5.629 & 4.836 & 8.229 \\
\hline \multirow[t]{5}{*}{ Fire + compression test } & Without addition & 19.556 & 10.938 & 4.864 & 8.466 & 5.406 & 11.199 \\
\hline & Polypropylene $1 \%$ & 32.549 & 9.593 & 5.598 & 8.355 & 10.039 & 16.154 \\
\hline & Polypropylene $2 \%$ & 28.270 & 12.665 & 5.832 & 8.529 & 9.138 & 14.729 \\
\hline & Steel 1\% & 30.186 & 10.988 & 5.859 & 8.776 & 8.851 & 14.663 \\
\hline & Steel $2 \%$ & 27.945 & 9.517 & 5.910 & 9.054 & 8.105 & 13.267 \\
\hline
\end{tabular}

(a)

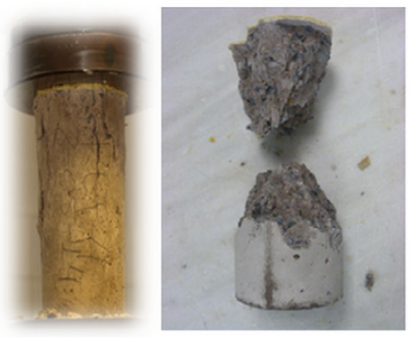

(b)

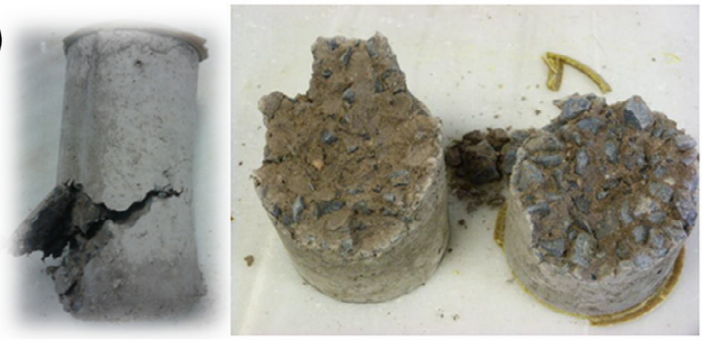

(c)

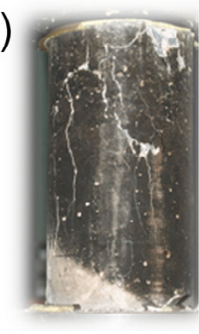

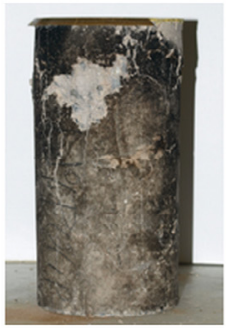

Fig. 8. Compression test in cylinder specimens with steel (a) and (b) polypropylene fibers before the fire test, and compression test in specimens with steel fibers after the fire test (c).

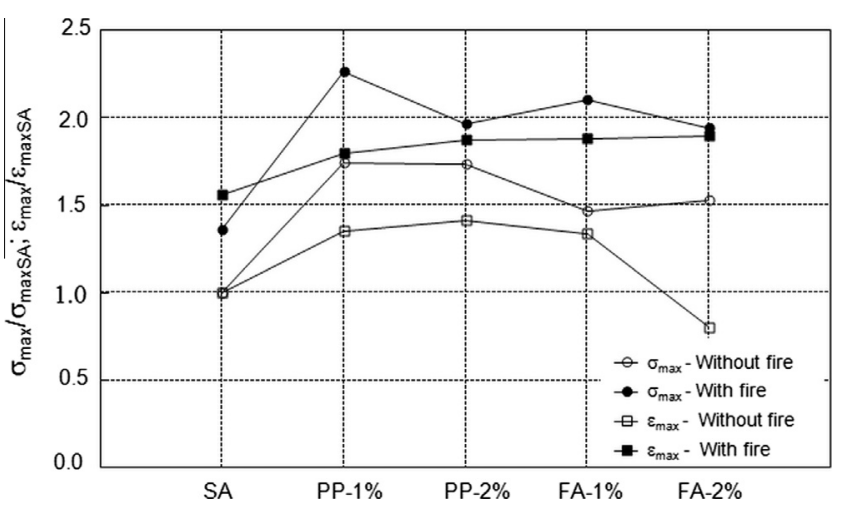

Fig. 9. Evolution of the mean values corresponding to the maximum strength and strain of the compression test, in specimens before and after the direct fire test.

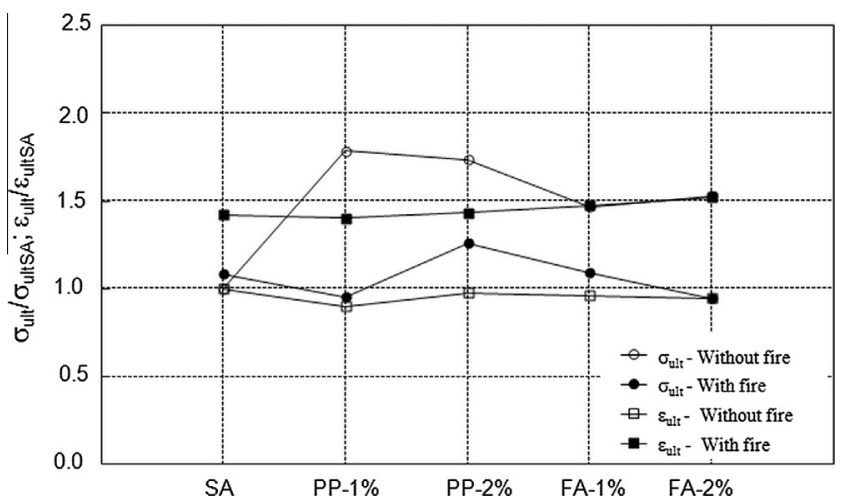

Fig. 10. Evolution of the mean values corresponding to the ultimate strengths and strains of the compression test, in specimens before and after the direct fire test.

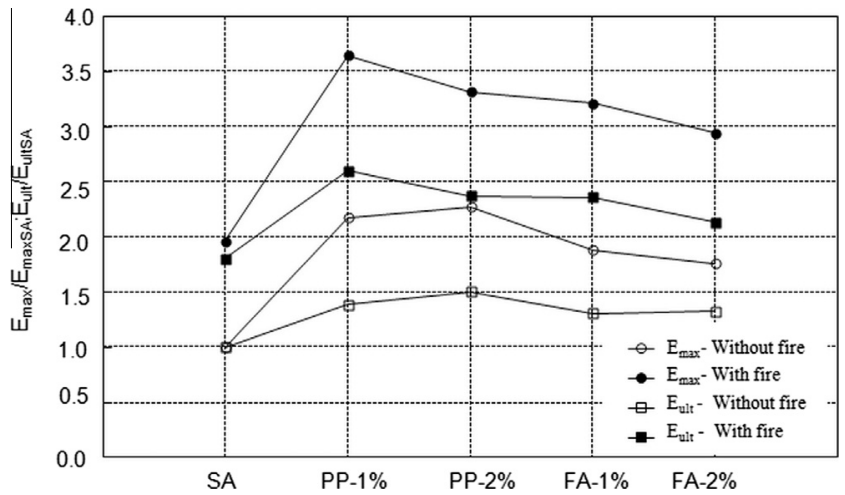

Fig. 11. Evolution of the mean values corresponding to maximum and ultimate strain energies obtained in the compression test, before and after the fire test.

produced in the specimens with additions, in contrast with the sudden cooling of specimens without additions.

Fig. 13 shows the relationship, in percentage (\%), between strengths corresponding to the mass concrete specimens at room temperature, and the other concrete specimens, with various additions and percentages, before and after, being subjected to the fire test. As can be seen, concrete with additions support higher strengths than the specimens without additions, having the best performance when $1 \%$ of polypropylene fiber per cement weight is added, both when exposed to fire and when at room temperature. Specimens increase their strength when exposed to fire at the temperature range studied, both in specimens without addition as in specimens with fibers. Major strength increases correspond to specimens with $1 \%$ addition, which implies that fiber additions higher than $1 \%$ do not have any impact regarding strength. 

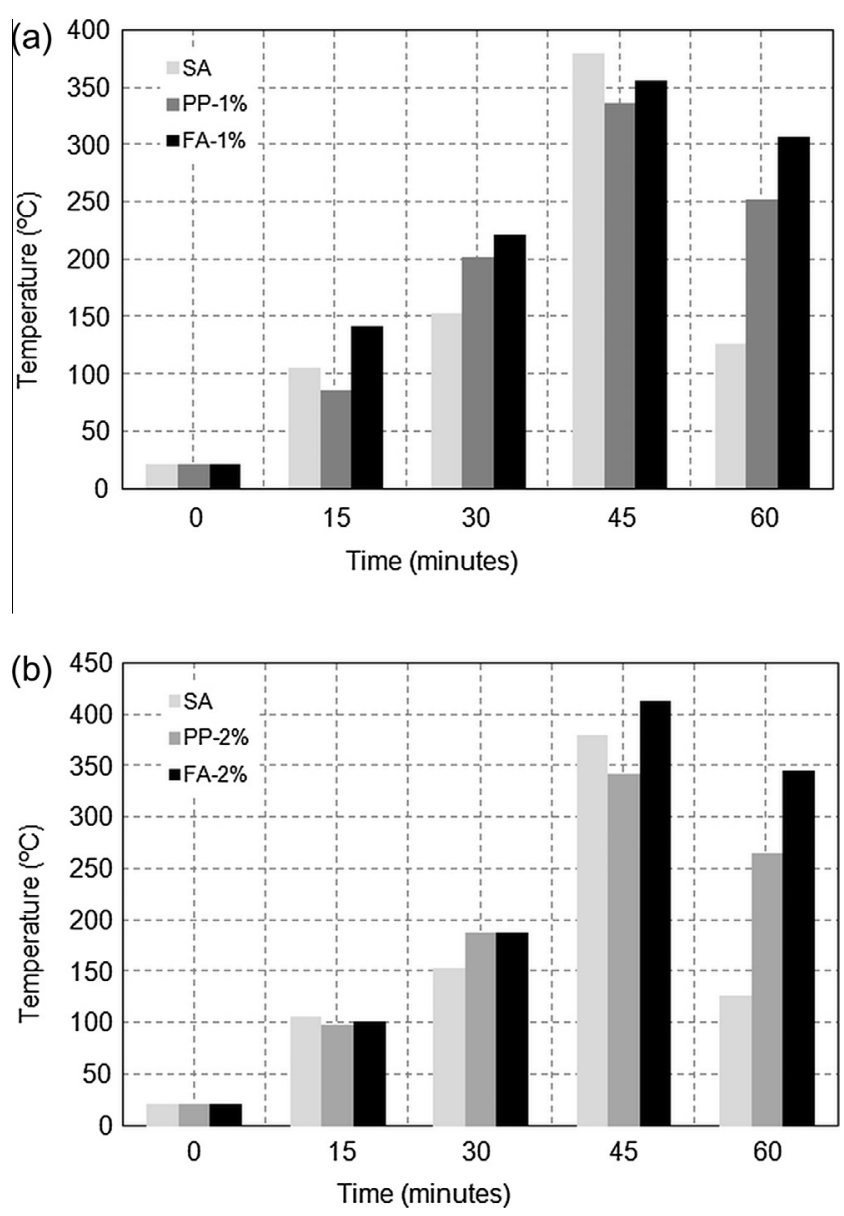

Fig. 12. Evolution of the mean temperatures reached in the direct fire test in specimens without additions, and with addition of $1 \%$ (a) and $2 \%$ (b).

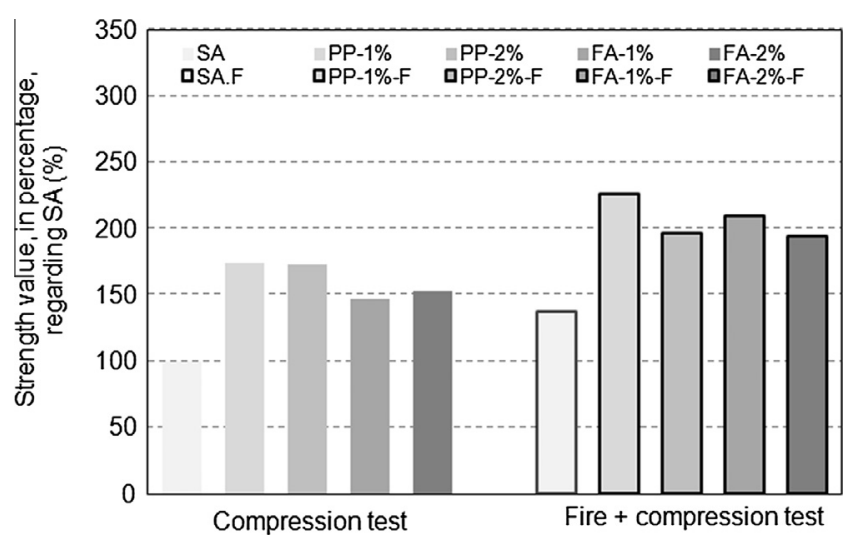

Fig. 13. Relationship between strengths, in percentage, depending the addition type and percentage, before and after the fire test, respect to specimens without addition before fire test.

\section{Conclusions}

From the result analysis shown in this study, the following conclusions can be drawn:

- Concrete with addition of polypropylene fibers and steel fibers in percentages of 1 and 2\% by weight achieve greater compression strength than without additions, but they lose ductility after the maximum strength has been reached.
- Under normal environmental conditions, concrete with addition of polypropylene fibers reaches higher strength values than those with steel fibers, for percentage rates of 1 and $2 \%$ by cement weight.

- Concrete with addition of steel fibers, subjected to direct heat action, reaches higher temperatures than concrete without additions. On the other hand, concrete with polypropylene fibers, due to its greater permeability at high temperatures, reaches lower temperatures than those of the previous cases.

- Concrete with addition of polypropylene or steel fibers, subjected to the direct heat action, cool more slowly than concrete without additions. The important characteristics polypropylene fibers confer to concrete, due to their ability to decrease pressure in the pore network when subjected to high temperatures, significantly reduces cracking in concrete.

- Compressive strength of concrete with polypropylene fibers or steel fiber additions is greater than that of concrete without additions, when subjected to thermal aggressions of $400{ }^{\circ} \mathrm{C}$ maximum temperature, although concrete ductility reduces once the maximum strength is reached.

- Incorporating polypropylene fibers is a good alternative to traditional concrete, since it improves its strength and its behavior in case of fire. Also, the addition of steel fibers presents advantages compared to traditional concrete, although the former is not able to achieve the performance obtained when adding polypropylene fibers.

\section{References}

[1] L Vega, M. Burón, Seguridad frente al fuego de las estructuras de hormigón, Instituto de ciencias de la construcción Eduardo Torroja, Madrid, 2007.

[2] M. Ring, R. Zeiml, Underground concrete frame structures subjected to fire loading: Part I - large-scale fire tests, Eng. Struct. 58 (2014) 175-187.

[3] C.D. Eamon, E. Jensen, Reliability analysis of reinforced concrete columns exposed to fire, Fire Saf. J. 62 (2013) 221-229.

[4] S. Bratina, B. Cas, M. Saje, I. Planinc, Numerical modelling of behaviour of reinforced concrete columns in fire and comparison with Eurocode 2, Int. J. Solids Struct. 42 (2005) 5715-5733.

[5] V.K.R. Kodur, M. Dwaikat, A numerical model for predicting the fire resistance of reinforced concrete beams, Cem.Concr. Compos. 30 (2008) 431-443.

[6] D. Capua, A.R. Mari, Nonlinear analysis of reinforced concrete cross sections exposed to fire received, Fire Saf. J. 42 (2007) 139-149.

[7] Y. Doo-Yeol, M. Kyung-Hwan, L. Joo-Ha, Y. Young-Soo, Shrinkage and cracking of restrained ultra-high-performance fiber-reinforced concrete slabs at early age, Constr. Build. Mater. 73 (2014) 357-365.

[8] AENOR, UNE-EN 14889-1:2008, Fibras para hormigón. Parte 1: Fibras de acero. Definiciones, especificaciones y conformidad, AEN/CTN 83, Hormigón, España, 2008.

[9] B. Haselwander, W. Jonas, H. Riech, Material equations for steel fibre reinforced concrete members, Nucl. Eng. Des. 156 (1-2) (1995) 235-248.

[10] J. Tailhan, P. Rossi, D. Daviau-Desnoyers, Probabilistic numerical modelling of cracking in steel fibre reinforced concretes (SFRC) structures, Cem. Concr. Compos. 55 (2015) 315-321.

[11] D.L. Nguyen, G.S. Ryu, K.T. Koh, D.J. Kim, Size and geometry dependent tensile behavior of ultra-high-performance fiber-reinforced concrete, Compos. B 58 (2014) 279-292.

[12] A. Abrishambaf, J.A. Barros, V.M.C.F. Cunha, Tensile stress-crack width law for steel fiber reinforced self-compacting concrete obtained from indirect (splitting) tensile tests, Cem. Concr. Compos. 57 (2015) 153-165.

[13] AENOR, UNE-EN 14889-2:2008, Fibras para hormigón. Parte 2: Fibras poliméricas, Definiciones, especificaciones y conformidad, AEN/CTN 83, Hormigón España, 2008.

[14] A.M. López-Buendía, M.D. Romero-Sánchez, V. Climent, C. Guillem, Surface treated polypropylene (PP) fibres for reinforced concrete, Cem. Concr. Res. 54 (2013) 29-35.

[15] A.A. Ramezanianpour, M. Esmaeili, S.A. Ghahari, M.H. Najafi, Laboratory study on the effect of polypropylene fiber on durability, and physical and mechanical characteristic of concrete for application in sleepers, Constr. Build. Mater. 44 (2013) 411-418.

[16] S. Kakooei, H.M. Akil, M. Jamshidi, J. Rouhi, The effects of polypropylene fibers on the properties of reinforced concrete structures, Constr. Build. Mater. 27 (2012) 73-77.

[17] J. Kim, G.P. Lee, D.Y. Moon, Evaluation of mechanical properties of steel-fibrereinforced concrete exposed to high temperatures by double-punch test, Constr. Build. Mater. 79 (2015) 182-191. 
[18] J. Bednář, F. Wald, J. Vodička, A. Kohoutková, Experiments on membrane action of composite floors with steel fibre reinforced concrete slab exposed to fire, Fire Saf. J. 59 (2013) 111-121.

[19] F. Rustin, K. Venkatesh, Enhancing the fire resistance of composite floor assemblies through the use of steel fiber reinforced concrete, Eng. Struct. 33 (10) (2011) 2870-2878

[20] A. Bilodeau, V.K.R. Kodur, G.C. Hoff, Optimization of the type and amount of polypropylene fibres for preventing the spalling of lightweight concrete subjected to hydrocarbon fire, Cem. Concr. Compos. 26 (2004) 163-174.

[21] P. Lura, G. Pietro Terrasi, Reduction of fire spalling in high performance concrete by means of super absorbent polymers and polypropylene fibers. Small scale fire tests of carbon fiber reinforced plastic prestressed selfcompacting concrete, Cem. Concr. Compos. 49 (2014) 36-42.

[22] J. Bošnjak, J. Ožbolt, R. Hahn, Permeability measurement on high strength concrete without and with polypropylene fibers at elevated temperatures using a new test setup, Cem. Concr. Res. 53 (2013) 104-111.

[23] A.N.S. Al Qadi, S.M. Al-Zaidyeen, Effect of fiber content and specimen shape on residual strength of polypropylene fiber self-compacting concrete exposed to elevated temperatures, J. King Saud Univ. Eng. Sci. 26 (2014) 33-39.

[24] M. Uysal, H. Tanyildizi, Estimation of compressive strength of self compacting concrete containing polypropylene fiber and mineral additives exposed to high temperature using artificial neural network, Constr. Build. Mater. 27 (2012) 404-414.

[25] P. Kalifa, G. Chéné, C. Gallé, High-temperature behaviour of HPC with polypropylene fibres. From spalling to microstructure, Cem. Concr. Res. 31 (2001) 1487-1499.

[26] P. Kalifa, F.D. Menneteau, D. Quenard, Spalling and pore pressure in HPC at high temperatures, Cem. Concr. Res. 30 (2000) 1915-1927.

[27] A. Noumowe, Mechanical properties and microstructure of high strength concrete containing polypropylene fibres exposed to temperatures up to $200{ }^{\circ} \mathrm{C}$, Cem. Concr. Res. 35 (2005) 2192-2198.

[28] Y. Ding, C. Zhang, M. Cao, Y. Zhang, C. Azevedo, Influence of different fibers on the change of pore pressure of self-consolidating concrete exposed to fire Constr. Build. Mater. 113 (2016) 456-469.

[29] AENOR, UNE-EN 197-1:2011, Cemento. Parte 1: Composición, especificaciones y criterios de conformidad de los cementos comunes, AEN/CTN 80 - Cementos y cales, España, 2011.

[30] RC-08, Instrucción para la recepción de cementos Con comentarios de los miembros de la Comisión Permanente del cemento, Secretaría Técnica, España 2009.
[31] AENOR, UNE-EN 13139/AC:2004, Áridos para morteros, AEN/CTN 146 - Áridos, España, 2004.

[32] AENOR, UNE-EN 12620:2003+A1:2009, Áridos para hormigón, AEN/CTN 146 Áridos, España, 2009.

[33] EHE, Instrucción de Hormigón Estructural, Ministerio De Fomento, Madrid, Spain, 2008.

[34] AENOR, UNE-EN 12390-1:2013: Ensayos de hormigón endurecido. Parte 1: Forma, dimensiones y otras características de las probetas y moldes, AEN/CTN 83 - Hormigón, España, 2013.

[35] AENOR. UNE-EN 12390-3:2009, Ensayos de hormigón endurecido. Parte 3: Determinación de la resistencia a compresión de probetas, AEN/CTN 83, Hormigón, España, 2009.

[36] AENOR, PNE-EN 1363-1: 2012, Ensayos de resistencia al fuego. Parte 1: Requisitos generales, AEN/CTN 23 - Seguridad contra incendios, España, 2012.

[37] AENOR, UNE-EN 1363-2:2000, Ensayos de resistencia al fuego. Parte 2: Procedimientos alternativos y adicionales, AEN/CTN 23 - Seguridad contra incendios, España, 2000.

[38] AENOR, UNE-EN 1365-4:2000, Ensayos de resistencia al fuego de los elementos portantes. Parte 4: Pilares, AEN/CTN 23 - Seguridad contra incendios, España, 2000.

[39] AENOR, UNE-EN 12390-2:2009, Ensayos de hormigón endurecido. Parte 2: Fabricación y curado de probetas para ensayos de resistencia, AEN/CTN 83, Hormigón, España, 2009.

[40] ISO 834-1:1999, Fire-Resistance Tests - Elements of Building Construction Part 1: General Requirements, 2015.

[41] P. Pliya, A.-L. Beaucour, A. Noumowé, Contribution of cocktail of polypropylene and steel fibres in improving the behaviour of high strength concrete subjected to high temperature, Constr. Build. Mater. 25 (2011) 1926-1934.

[42] M.C. Alonso, C. Rodriguez, M. Sánchez, B. Barragan, Respuesta al fuego de HAC con y sin refuerzo de fibras, in: bac2010 - $2^{\circ}$ Congresso Ibérico sobre betão auto-compactável. $2^{\circ}$ Congreso Ibérico sobre Hormigón Autocompactant, Guimarães, 2010.

[43] N. Toropovs, F. LoMonte, M. Wyrzykowski, B. Weber, G. Sahmenko, P. Vontobel, R. Felicetti, P. Lura, Real-time measurements of temperature, pressure and moisture profiles in high-performance concrete exposed to high temperatures during neutron radiography imaging, Cem. Concr. Res. 68 (2015) 166-173. 